\title{
THE DETERMINANTS OF CAPITAL STRUCTURE ON PROPERTY AND REAL ESTATE COMPANY PERIOD 2012-2016
}

\author{
Rani Ranitasari ${ }^{\bowtie}$, Ida Maftukhah
}

Management Department, Faculty of Economics, Universitas Negeri Semarang, Semarang, Indonesia

\section{Info Article}

History Article:

Received August 2018

Approved November 2018

Published December 2018

Keywords:

Asset Growth; Asset Structure, Captal Structure; Firm Size; Liquidity; Proftability.

\begin{abstract}
The research aims to know the determinant of capital structure. Population in this research is property and real estate company listed in Indonesia Stock Exchange period 2012-2016. The sample in this research is determined based on purposive sampling which is a sampling technique based on certain criteria. Companies that meet the criteria of the sample are 30 companies with research period for 4 years, so obtained the data of 150 observations. The analysis used was multiple linear regression analysis which was preceded by panel data model selection and classical assumption test. The result of random effect model regression test shows that profitability and liquidity have a significant negative effect on capital structure, while asset growth has a significant positive effect on capital structure, but the firm size and asset structure had no significant positive effect on capital structure.
\end{abstract}

\begin{abstract}
Abstrak
Penelitian ini bertujuan untuk mengetahui faktor-faktor yang mempengaruhi struktur modal. Populasi dalam penelitian ini adalah perusahaan property and real estate yang terdaftar di Bursa Efek Indonesia tahun 2012-2016. Sampel dalam penelitian ini ditentukan berdasarkan purposive sampling yaitu teknik pengambilan sampel berdasrkan kriteria tertentu. Perusahaan yang memenuhi kriteria sampel sejumlah 30 perusahaan dengan periode penelitian empat tahun sehingga diperoleh data sebanyak 150 observasi. Analisis yang digunakan adalah analisis regresi linear berganda yang didahului pemilihan model data panel dan pengujian asumsi klasik. Hasil uji regresi random effect model menunjukan bahwa profitabilitas dan likuiditas berpengaruh negatif signifikan terhadap struktur modal, sedangkan pertumbuhan aset berpengaruh positif signifikan terhadap struktur modal, namun ukuran perusahaan dan struktur aktiva berpengaruh positif tidak signifikan terhadap struktur modal.
\end{abstract}




\section{INTRODUCTION}

The increasingly competitive business competition is unavoidable. Therefore each company is expected to continue to grow and maintain its competitive edge. The company's development efforts is a problem for any company, as it concerns the fulfillment of the necessary funds (Hendratmoko \& Laily, 2017).

The amount of capital required for each company will vary according to the size of the company (Haruman, 2008). There are two sources of financing that can be used by the company, which is a source of financing that comes from within the company itself (internal financing) and the source of financing comes from outside the company (external financing). The perspective pecking order theory explains that the company is more likely to choose the funding comes from internal rather than external.

The financial manager in charge of managing the funds necessary to consider the use of funds and decision-making fulfillment of funds to achieve its goals which have been set (Riyanto, 1995). The company's goal is basically to maximize the welfare of the owners (shareholders) through a decision or investment policy, financing and dividends are reflected in stock prices in the capital market. The higher the stock price means the welfare of the owners is increasing (Maftukhah, 2013).

One of the most important decisions facing financial managers in relation to the fulfillment of the decision of the fund is financing decisions or decisions of capital structure, which is a financial decision relating to the composition of debt, preferred stock and common stock to be used by the company (Indriani \& Widyarti, 2013). Managers must be able to determine the appropriate source of funding for running and developing the company's investment activities and operational (Nisak \& Ardiansari, 2016).

The decision determining the capital structure is important because of the determination of capital structure associated with the development of capital costs. Determination of the optimal capital structure makes the company run effectively and efficiently by minimizing the cost of capital (Thesarani, 2016). Decision capital structure or financing decisions that are not carefully and will lead to high cost of capital received by the company as well as threaten the company's financial position (Insiroh, 2014).

In making capital structure decisions, companies need to consider and analyze the combination of the sources of funds that will be used (Ridloah, 2010). The right combination in the selection of the chosen capital structure will be able to produce an optimal capital structure that is able to be a strong foundation for the company to run its production activities and can bring optimal benefits for the company and its shareholders (Sari \& Haryanto, 2013).

According to Firnanti (2011), the optimal capital structure is a condition in which a company can use a combination of debt and equity is an ideal that is balancing the company's value and the cost of its capital structure. According to Widodo and Djawahir (2014), the optimal capital structure can be achieved if the weighted average cost is low.

The problem of capital structure is an important issue for any company, for good and bad capital structure of the company will have a direct impact on the financial position of the company (Bambang, 2001). In addition, according to Nugraha (2013) changes in the company's capital structure will affect the level of risk faced by the company in the capital. Therefore, in setting the company's capital structure need to consider various factors that influence it. With the factors that affect the company's capital structure becomes important as a basis for determining the composition of the company's capital structure.

According to Brigham and Houston, (2006), there are several factors that affect the capital structure including stability sales, asset structure, operating leverage, profitability, growth rate, tax, control, management attitude, the attitude of lenders and donor agency ratings, market conditions, the company's internal conditions and financial flexibility. This study will be discussed factors affecting the company's capital structure decisions among other things: profitability, size firms, asset growth, asset structure and liquidity.

According to Indriani and Widyarti (2013), ROA increase will allow the increase in retained earnings, so the equity component will be increased so that the ratio of debt to decrease. This is in line with the pecking order theory which has the first funding preference with internal funds in the form of retained earnings, thus increasing equity component. However, there is the fact that when ROA increased DER also increased, it happened in 2013 and when ROA decreased DER also decreased which occurred in 2014 and 2016. According to Noor et al. (2015) profitability has a significant negative effect on the capital structure while according to Nugroho (2014) profitability has a significant positive effect on the capital structure. 
Table 1. The average capital structure, profitability, company size, growth assets, structure and liquidity assets in property and real estate company listed in Indonesia Stock Exchange year 2012-2016

\begin{tabular}{lrrrrr}
\hline \multirow{2}{*}{\multicolumn{1}{c}{ variables }} & \multicolumn{5}{c}{ Year } \\
\cline { 2 - 6 } & $\mathbf{2 0 1 2}$ & $\mathbf{2 0 1 3}$ & $\mathbf{2 0 1 4}$ & $\mathbf{2 0 1 5}$ & $\mathbf{2 0 1 6}$ \\
\hline Debt to Equity Ratio (DER) & .740 & .763 & .747 & .745 & .707 \\
Return on Assets (ROA) & .055 & .070 & .068 & .084 & .052 \\
Firm Size (SIZE) & 27.152 & 27.408 & 27.534 & 27.875 & 27.940 \\
Assets Growth (AG) & .513 & .487 & .147 & .260 & .071 \\
Assets Structure (SA) & .572 & .587 & .575 & .599 & .606 \\
Current Ratio (CR) & 2.315 & 2.445 & 2.765 & 2.907 & 3.687 \\
\hline
\end{tabular}

The data from the property and real estate company listed in Indonesia Stock Exchange can be seen in Table 1.

Large companies generally have large sales levels and generating greater profit level, so that the financing needs will be met by using internal resources (Wikartika \& Fitriyah, 2017). This is in line with the pecking order theory which has the first funding preference with internal funds. The higher the value of the firm size, the lower the DER. However, there is the fact that when SIZE increased, DER also increased which occurred in 2013. According to Nirmala et al. (2016) firm size has a significant negative effect on the capital structure while according to Indriani \& Widyarti (2013) firm size has a significant positive effect on the capital structure.

Growth is defined as the annual change in total assets. Pecking order theory states that companies with a high growth rate will be expanded by using external funds in the form of debt. However, there is the fact that when the asset growth has decreased, DER has increased, namely in 2013 and 2015. According to Joni and Lina (2010) asset growth has a significant negative effect on the capital structure while according to Sari \& Haryanto (2013) asset growth is not significant positive effect on the capital structure.

When a company has a proportion greater tangible asset, assets appraisal becomes easier so that the problem of information asymmetry becomes lower. Thus, the company will reduce the use of debt while increasing the proportion of tangible assets (Hadianto, 2008). This is in line with the pecking order theory which states that the structure of assets has a negative effect on capital structure, means that if the asset structure increased DER will also decrease. However, there is the fact that when the SA has increased, DER also increased which occurred in 2013 and when SA decreased DER also experienced decreasing that occurred in 2014. According to Kartika (2009) asset structure has a significant positive effect on the capital structure while according to Hartoyo et al. (2014) asset structure has a significant negative effect on the capital structure.

The level of liquidity describes the company's ability to pay its short-term liabilities by using current assets (Wimelda \& Marlinah, 2013). Based on the pecking order theory states that companies that have a high level of liquidity will be less likely to use debt financing. However, there is the fact that when liquidity increases, DER declined which occurred in 2013. According to Sansoethan \& Suryono (2016), liquidity has a significant negative effect on the capital structure while according to Ridloah (2010) liquidity has a significant positive effect on the capital structure.

Industrial property and real estate is an industry engaged in the construction of public utility buildings. Business property and real estate are a very lucrative business opportunity in Indonesia. However, all countries, including Indonesia, the industrial sector property and real estate is a sector with characteristics that are difficult to predict and high risk. Unpredictable means, an amplitude of this sector has been heavily influenced by economic growth. It also contains a high risk, this is due to the financing or the major source of funding for this sector is generally obtained through bank credit in the form of debt, so it needs special attention to examine the capital structure of the company's property and real estate.

Based on the above description, the formulation of the problem posed is whether profitability has a significant negative effect on the capital structure? whether the firm size has a significant negative effect on the capital structure? whether the asset growth has a significant positive effect on the capital structure? whether the asset structure has a significant negative effect on the capital 
structure? and liquidity has a significant negative effect on the capital structure?

From the formulation of the problem above, the purpose of this study was to determine the significant influence profitability, firm size, asset growth, asset structure and liquidity to capital structure.

\section{Hypothesis Development}

Profitability shows the balance of income and the ability of firms to generate profits at different levels of operation (Wibowo \& Wartini, 2012). Companies that have a high profit allows for the use of retained earnings (retained earnings) as sources of funds (Wahyuni, 2012). According to Nuswandari (2013) companies that have high profitability is likely to reduce debt. This is due to the company allocates the majority of its profits to the retained earnings that rely on internal resources and relatively low use of debt. According to Sari \& Haryanto (2013) increased profitability will increase retained earnings, so the company will use funding from internal funds in the form of retained earnings.

Brigham \& Houston (2006) adds that companies with high return on investment, using debt is relatively small, because of the huge profits meal companies will have the funds and retained earnings that great anyway, so it will incline to use retained earnings compared with add to the debt. The higher profitability, the lower the capital structure. In accordance with the pecking order theory, companies tend to be prioritized for further use internal funds and external funds. This is consistent with research Indriani and Widyarti (2013) which states that the profitability of a significant negative effect on the capital structure.

H1: Profitability has a significant negative effect on the capital structure.

According to Nuswandari (2013) firm size described the size of a company, the larger the size of a company, the greater the funds needed by the company in running the company's operations. Large companies generally have large sales levels and generating greater profit level. Large funding needs are met by the use of internal resources (Wikartika \& Fitriyah, 2017). In accordance with the pecking order theory that prefers to use internal rather than external funds of funds. The larger the company, the lower the capital structure. This is consistent with research Nugroho (2014) and Nirmala et al. (2016) which states that firm size has a significant negative effect on the capital structure.
H2: Firm size has a significant negative effect on the capital structure.

Growth in assets is an overview of the company placing the funds for operating and investing activities. To increase the assets owned by the company, both current assets and fixed assets in need of funds, where the funds can be obtained through internal funds and external funds (Firnanti, 2011). Besides According to Sari and Oetomo (2016) companies with a high growth rate will be expanded by using external funds in the form of debt. Therefore the company is in a period of high growth will tend to use more debt. Asset growth has a positive effect on the capital structure, as companies with a high growth rate will depend on funds from outside the company because of the company's funds are not sufficient to support a high growth rate.

In accordance with the pecking order theory, if external funding is required, the company will choose the order was first used is to choose the safest securities, namely debt rather than shares. This is consistent with research Joni and Lina (2010) stating that the asset growth has a significant positive effect on the capital structure.

H3: Growth asset has a significant positive effect on the capital structure.

The company's asset structure has an influence on the sources of financing. According to Riyanto (1995) most industrial companies where the majority of their capital rather than embedded in fixed assets (fixed assets), will give priority to the capital of permanent capital, capital itself, while its debt as complementary. It is associated with a conservative capital structure horizontal rule which states that the amount of equity capital should be at least be able to cover the number of fixed assets plus other assets that are harvesters. In line with the pecking order theory, firms tend to be prioritized for further use internal funds and external funds.

According to Hadianto (2008), the main problem in the pecking order theory lies in information asymmetry. When companies have a fixed proportion of larger assets, the valuation of its assets to more easily so that the problem of information asymmetry becomes lower. thus, the company will reduce the use of debt while increasing the proportion of fixed assets. This is consistent with research Hamidah (2016) stating that the asset structure has a significant negative effect on the capital structure.

H4: Asset structure has a significant negative effect on the capital structure. 
The liquidity ratio is the level of the company's ability to meet its short-term liabilities with its current assets. Liquidity is negatively related to capital structure. In accordance with the pecking order theory, companies that have high liquidity will tend not to use debt financing. This is due to the company the company with a high level of liquidity which has a large internal fund so that the company will be using internal funds to finance its investment in advance before using external financing through debt. This is consistent with research Liang et al. (2014) which states that the liquidity has a significant negative effect on the capital structure.

H5: Liquidity significant negative effect on the capital structure

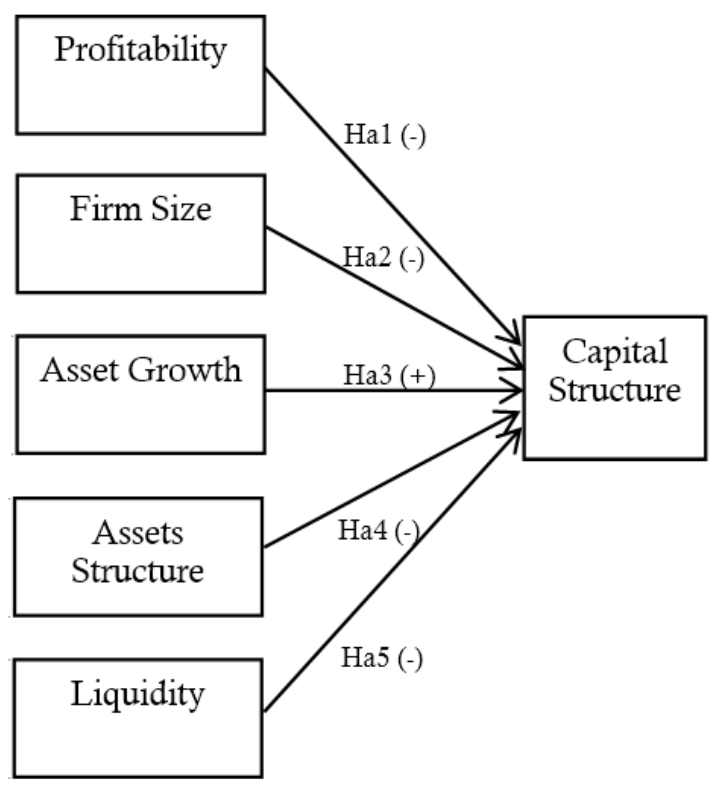

Figure 1 Theoretical Framework

\section{METHOD}

This type of research used in this research using quantitative methods. The method used in this research is the method of documentation to collect data relating to profitability, firm size, asset growth, asset structure, liquidity and capital structure. Source data used are secondary data obtained from the financial statements of property and real estate company listed on the Indonesia Stock Exchange in 2012-2016. The financial statements were obtained from the Indonesia Stock Exchange's website (www.idx.co.id).

The population in this study are the companies property and real estate listed on the Indonesia Stock Exchange in 2012-2016. Total population in this study was 49 companies. Techniques in sample selection using the purposive sampling.
This technique gives freedom to the researchers so that researchers can determine the sampling in accordance with the purpose of research (Oktavilia et al., 2017). The criteria used are (a) property and real estate company listed on the Indonesia Stock Exchange from 2012 to 2016 (b) Vendor actively to publish financial statements for five consecutive in 2012 to 2016. (c) the company does not suffer losses in 2012-2016. (d) the company does not delist and relisting on the Indonesia Stock Exchange between the period of 2012 through 2016. Companies that meet the criteria for a sample of 30 company with 5 years of the study period of 150 observation data obtained.

The dependent variable in this study is the debt to equity ratio. While the independent variables used in this study is profitability, firm size, growth assets, structure assets and liquidity. According to Wachowicz and Van Horne (2007) capital structure is the mix (proportion) long-term financing as outlined in the debt, equity, preferred stock and common stock. The capital structure is formulated with:

$$
D E R=\frac{\text { Total Debt }}{\text { Total Equity }}
$$

Profitability ratios measure a company's ability to generate profits by using the resources of the company, such as assets, capital or sale of the company (Sudana, 2015). In this study the profitability of proxies using ROA. According to Sudana (2015), ROA is formulated as follows:

$$
R O A=\frac{\text { Earning After Tax }}{\text { Total Assets }}
$$

According to Haryanto (2014), firm size described the size of a company that is indicated by the total assets owned, the number of sales, average total sales and average assets. Firm size measured by the natural logarithm of total assets (Yulianto et al., 2016):

$$
\text { Size }=\text { Ln (Total Assets) }
$$

The growth of the company shows the company's ability to survive in the conditions of competition. Asset growth shows the level of asset growth from the previous period (Sutrisno, 2016). According to Indrajaya et al. (2011) systematically asset growth can be formulated as follows:

$$
A G=\frac{\text { Total Assets }(t)-\text { Total Assets }(t-1)}{\text { Total Assets }(t-1)}
$$


The structure of assets is the ratio between fixed assets and total assets (Weston \& Copeland, 1996). According to Seftianne and Handayani (2011), asset structure describes the most amount of assets that can be pledged as security (collateral value of assets). According to Brigham and Weston (2005), the asset structure is formulated as follows:

$$
\text { Assets Structure }=\frac{\text { Fixed Assets }}{\text { Total Assets }}
$$

Liquidity is the ratio used to measure a company's ability to pay short-term obligations (Wachowicz \& Horne, 2005). In this study, the liquidity proxied by using the current ratio According to Brigham \& Houston (2014) current ratio can be expressed as follows:

$$
\text { Current Ratio }=\frac{\text { Current Assets }}{\text { Current Liabilities }}
$$

Data analysis techniques used in this research is multiple linear regression analysis. Before performing multiple linear regression analysis, performed the selection panel data model through the test chow, Hausman test and test Lagrange multiplier. Furthermore, to test the classical assumption of normality test, multicollinearity, heteroscedasticity test and autocorrelation. Hypothesis testing is done through multiple linear regression analysis. Multiple linear regression analysis is used to determine the effect of profitability, firm size, asset growth, asset structure and the liquidity of the capital structure. Multiple linear regression equations in this study as follows:

$$
\mathrm{Y}=\alpha+\beta_{1} \mathrm{X} 1+\beta_{2} \mathrm{X} 2+\beta_{3} \mathrm{X} 3+\beta_{4} \mathrm{X} 4+\beta_{5} \mathrm{X} 5+\mu
$$

Information:

Y : Capital Structure (DER)

$\alpha \quad$ : Constants

$\beta \quad$ : Regression coefficient

X1 : Profitability (ROA)

$\mathrm{X} 2$ : Firm Size (SIZE)

$\mathrm{X} 3$ : Asset Growth(AG)

$\mathrm{X} 4$ : Asset Structure (SA)

$\mathrm{X} 5$ : Liquidity (CR)

$\mu$ : Error

\section{RESULT AND DISCUSSION}

\section{Descriptive statistics}

Based on Table 2, capital Structure (DER) has a minimum value of 0.074 , the maximum value of 2.850. The average (mean) of 0.830 and a standard deviation of 0.485 . The average value (mean) greater than the standard deviation is $0.830>0.485$ it shows good data dissemination.

Profitability (ROA) have value amounted minimum 0.001 , the maximum value of 0.316 . The average (mean) of 0.074 and a standard deviation of 0.053 . The average value (mean) greater than the standard deviation is as big as $0.074>$ 0.053 it shows good data dissemination.

Firm size (SIZE) has a minimum value of 21.693 , maximum value 31.451 . The average (mean) of 27.854 and a standard deviation of 2.757. The average value (mean) greater than the standard deviation is $27.854>2.757$ it shows good data dissemination.

Asset growth (AG) has a minimum value of -0.164 , the maximum value of 1.970 . The average (mean) of 0.188 and a standard deviation of 0.238 . The average value (mean) less than the standard deviation of that $0.188<0.238$ then this shows that the spread of the data is less good.

Asset structure (SA) has a minimum value of 0.000 , the maximum value of 0.846 . The average (mean) of 0.106 and a standard deviation of 0.163 . The average value (mean) less than

Table 2. Descriptive Statistics Test Results

\begin{tabular}{ccrrrc}
\hline & N & Max & \multicolumn{1}{c}{ Min } & Mean & Std. Dev \\
\hline DER & 150 & 2.850 & .074 & .830 & .485 \\
ROA & 150 & .316 & .001 & .074 & .053 \\
SIZE & 150 & 31.451 & 21.693 & 27.854 & 2.757 \\
AG & 150 & 1.970 & -.164 & .188 & .238 \\
SA & 150 & .846 & .000 & .106 & .163 \\
CR & 150 & 8.801 & .240 & 2.186 & 1.470 \\
\hline
\end{tabular}


the standard deviation is $0.106<0.163$ then this shows that the spread of the data is less good.

Liquidity (CR) has a minimum value of 0.240 , The maximum value of 8.801 . The average (mean) of 2.186 and the value of a standard deviation of 1.470 . The average value (mean) greater than the standard deviation is as big as $2.186>1.470$ it shows good data dissemination.

\section{Selection of Panel Data Model}

The following is the result of choosing a panel data estimation model through a chow test, Hausman test and Lagrange multiplier test :

Table 3. Chow Test Results

\begin{tabular}{lccc}
\hline \multicolumn{1}{c}{ Effect Test } & Statistics & Df & Prob \\
\hline $\begin{array}{l}\text { Cross-Section F } \\
\text { Cross Section }\end{array}$ & 14.274615 & $(29.115)$ & .0000 \\
Chi-Square & 228.898189 & 29.000 & .0000 \\
\hline
\end{tabular}

Based on the result of the chow test, the probability value of Cross Section Chi-Square < 0.05 so that the selected model is a fixed effect.

Table 4.Hausman Test Results

\begin{tabular}{llll}
\hline Test Summary & $\begin{array}{c}\text { Chi-Chi-Sq } \\
\text { SqStatistic }\end{array}$ & Df & Prob \\
\hline $\begin{array}{l}\text { Cross-Section } \\
\text { random }\end{array}$ & 10.267986 & 5 & .0680 \\
\hline
\end{tabular}

Based on the result of the Hausman test, the probability value of Cross Section Random $<0.05$ so that the selected model is the random effect.

Table 5.Lagrange Multiplier Test Results

\begin{tabular}{lrrr}
\hline & \multicolumn{2}{l}{$\begin{array}{l}\text { Hypothesis Cross-sec- } \\
\text { tion Test Time }\end{array}$} & \multicolumn{1}{l}{ Both } \\
\hline Breusch- & 128.7342 & 2.103465 & 130.8377 \\
Pagan & $(.0000)$ & $(.1470)$ & $(.0000)$ \\
\hline
\end{tabular}

Based on the result Lagrange multiplier test probability value of cross section BreuschPagan $<0.05$ so that model was chosen is the random effect.

Based on the selection panel data model, the best panel data regression model that used in this research is the random effect model.

\section{Normality Test}

Residual data in this study is not the normal distribution, the researchers, because they were eliminating some of the detected data, is the data outliers. A number of preliminary observations used in this study were 150 observations. After the elimination of the data, outlier observations amount to 127 observations. Here are the results of tests of normality:

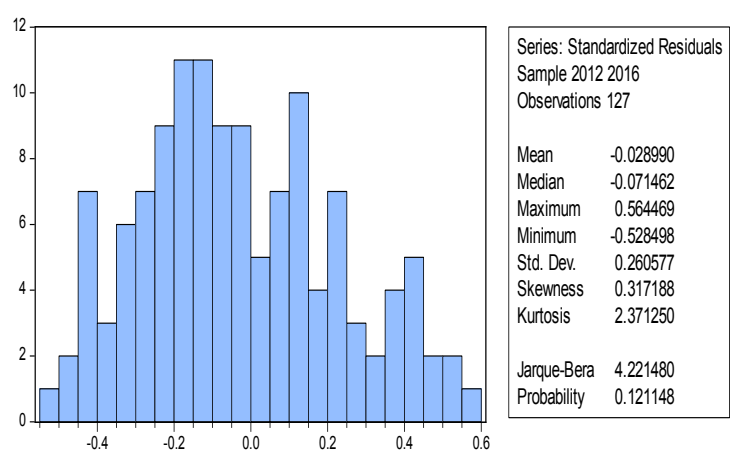

Figure 2. Normality Test Results

Based on the Figure 2, it can be seen that the probability of $0.12115>0.05(5 \%)$ then it means that the normal distribution of data.

\section{Heterokedastisitas Test}

Table 6. Heterokedastisitas Test Results

\begin{tabular}{cc}
\hline Variables & Probability \\
\hline C & .8682 \\
ROA & .5641 \\
SIZE & .3078 \\
AG & .3154 \\
SA & .1127 \\
CR & .3913 \\
\hline
\end{tabular}

Based on Table 6, heteroscedasticity test results using glejser test showed that the significance value of all the variables is greater than 0.05 so it does not happen heteroscedasticity.

\section{Multicollinearity Test}

Table 7. Multicollinearity Test Results

\begin{tabular}{cccccc}
\hline & ROA & SIZE & AG & SA & CR \\
\hline ROA & 1 & .107 & .452 & .219 & .001 \\
SIZE & .107 & 1 & .151 & .084 & .207 \\
AG & .452 & .151 & 1 & .018 & -.103 \\
SA & .219 & .084 & .018 & 1 & -.217 \\
CR & .001 & .207 & -.103 & -.217 & 1 \\
\hline
\end{tabular}


The correlation matrix in Table 7 all correlation coefficients between the independent variables are under 0.90 . It can be concluded that there is no multicollinearity.

\section{Autocorrelation Test}

Autocorrelation test results obtained by DW 0.831738 . DW value will be compared with initial DW table with a value of 0.05 with 127 observations and five independent variables $(\mathrm{k}$ $=5$ ). DU values obtained at 1.7928 . DW value for 0.831738 smaller than the upper limit $(\mathrm{dU}=$ 1.7928) and less than $4-\mathrm{dU}(4-1.7928=2.2072)$, indicating that the autocorrelation for $\mathrm{DW}$ value obtained is lower than the upper limit (dU) is $0.831738<1.7928$. Therefore, researchers corrected autocorrelation by adding lag dependent variable $\mathrm{Y} 1$ that $\mathrm{Yt}-1$. Here are the results of autocorrelation correction:

Table 8. Autocorrelation Test Result

\begin{tabular}{cc}
\hline $\begin{array}{l}\text { Durbin-Watson } \\
\text { before Add Lag }\end{array}$ & $\begin{array}{l}\text { Durbin Watson } \\
\text { after Add Lag }\end{array}$ \\
\hline .831738 & 1.974036 \\
\hline
\end{tabular}

Based on Table 8, the obtained autocorrelation correction DW value for 1.974036 . DW value 1.974036 is greater than the upper limit $(\mathrm{dU})$ equal to 1.7928 and less than $4-\mathrm{dU}(4-1.7928=$ 2.2072 ), we can conclude there is no autocorrelation problem in this study.

\section{Random Effect Regression Analysis Model}

Table 9. Regression with Random Effects Model

\begin{tabular}{|c|c|c|c|c|}
\hline Variable & Coefficient & Std. Error & t-Statistic & Prob. \\
\hline C & 215178 & . 145242 & 1.481508 & .1419 \\
\hline ROA & -1.834147 & .221649 & -8.274997 & .0000 \\
\hline SIZE & .001974 & .005464 & .361187 & .7188 \\
\hline AG & .570675 & .063792 & 8.945876 & .0000 \\
\hline SA & .016675 & .090107 & .185062 & .8536 \\
\hline CR & -.028489 & .009689 & -2.940423 & .0042 \\
\hline
\end{tabular}

Based on the test results of multiple linear regression with random effect model in table 9 regression equation as follows:

$$
\begin{aligned}
\mathrm{DER}= & 0.215178-1.834147 \mathrm{ROA}+0.001974 \\
& \mathrm{SIZE}+0.570675 \mathrm{SA}+0.016675 \mathrm{AG}- \\
& 0.028489 \mathrm{CR}+\mathrm{Wit}
\end{aligned}
$$

Table 10. Cross Section Random Effect (Firm Effect)

\begin{tabular}{cccccc}
\hline No & Firm & Effect & No & Firm & Effect \\
\hline 1 & BAPA & -.018368 & 15 & KIJA & .020143 \\
2 & BCIP & .074756 & 16 & LPCK & -.034877 \\
3 & BEST & .014334 & 17 & LPKR & -.005566 \\
4 & BKSL & -.043716 & 18 & MDLN & .002985 \\
5 & BSDE & -.014936 & 19 & MKPI & .054020 \\
6 & CTRA & .041943 & 20 & MTLA & .017819 \\
7 & DART & -.009517 & 21 & PLIN & .091349 \\
8 & DILD & .079952 & 22 & PUDP & -.027236 \\
9 & DUTI & -.007402 & 23 & PWON & -.053634 \\
10 & EMDE & .028156 & 24 & RDTX & -.028933 \\
11 & GMTD & -.048307 & 25 & RODA & -.027679 \\
12 & GPRA & -.006317 & 26 & SCBD & .003278 \\
13 & GWSA & -.018536 & 27 & SMDM & -.087758 \\
14 & JRPT & .004046 & & & \\
\hline
\end{tabular}

Based on Table 9, can be known the value of intercept (average) of 0.215178 . The results of the intercept (per-sachets) per company are presented in table 10 . The value of intercept difference will be compared with the value of intercept (average).

Table 11. The Goodness of Fit Test Results

\begin{tabular}{lr}
\hline R-squared & .847354 \\
\hline Adjusted R-squared & .837289 \\
\hline SE of regression & .089015 \\
\hline F-statistic & 84.191710 \\
\hline Prob (F-statistic) & .000000 \\
\hline
\end{tabular}

The coefficient of Determination Test

In Table 11 seen the value of Adjusted $\mathrm{R}$ Square of 0.837289 or $84 \%$, means that the ability of the independent variable in this study is profitability, firm size, asset growth, asset structure and liquidity can explain the capital structure proxied by debt to equity ratio of $84 \%$. While the rest of $16 \%$ is explained by other variables outside the model of this study.

\section{Statistic F Test}

Based on the test results in Table 11 probability (F-statistic) worth 0.000000 . The significance level of less than 0.05 so that it can be concluded that the profitability (ROA), firm size (SIZE), asset growth (AG), asset structure (SA) and liquidity (CR) simultaneously significant effect on the capital structure. 
Table 12. Hypothesis Test Results Summary

\begin{tabular}{|c|c|c|c|c|}
\hline Hypothesis & Variables & Coefficient & Prob. & Information \\
\hline Ha1 & Profitability & -1.834147 & .0000 & $\begin{array}{l}\text { significant negative } \\
\text { (Ha1 accepted) }\end{array}$ \\
\hline $\mathrm{Ha} 2$ & Firm Size & .001974 & .7188 & $\begin{array}{l}\text { Positive not significant } \\
\text { (Ha2 rejected) }\end{array}$ \\
\hline Ha3 & Asset Growth & .570675 & .0000 & $\begin{array}{l}\text { significant positive } \\
\text { (Ha3 accepted) }\end{array}$ \\
\hline $\mathrm{Ha} 4$ & Assets Structure & .016675 & .8536 & $\begin{array}{l}\text { Positive not significant } \\
\text { (Ha4 rejected) }\end{array}$ \\
\hline Ha5 & Liquidity & -.028489 & .0042 & $\begin{array}{l}\text { significant negative } \\
\text { (Ha5 accepted) }\end{array}$ \\
\hline
\end{tabular}

\section{Hypothesis Test (t-test)}

Testing this hypothesis using the t-test or partial. A t-test or partial test is intended to test whether the independent variable partially significant effect on the dependent variable.

Based on t-test results in Table 12 it can be seen that of the five independent variables in this study were tested partially shows that there are three variables: profitability (ROA), asset growth (AG) and liquidity (CR) has a probability value $<0,05$ means that the variable profitability, asset growth and liquidity partially influential and significant on the variable dependent capital structure proxied by debt to equity ratio (DER).

As for the variable firm size (SIZE) and the asset structure (SA) has a probability value of $>0.05$ so variable firm size (SIZE) and the asset structure (SA) partially no significant effect on the dependent variable capital structure proxied by debt to equity ratio (DER).

Results of statistical regression to the variable profitability of -1.834147 , statistical results of the t-test for the variable profitability of 0.0000 less than 0.05 means that the profitability has a significant negative effect on the capital structure. So the first alternative hypothesis is accepted. These results are consistent with research (Indriani \& Widyarti, 2013).

Profitability has a significant negative relation to capital structure. This means that Companies that obtain high profits will tend to use relatively low debt. The higher profitability shows that the retained earnings from the company are also high. If the high corporate profits, the company has more financial resources than in large enough, so that the company may need less debt. It can be concluded that companies will tend to choose funds from the company in the form of retained earnings for use in meeting the financing needs of the company.
Based on the pecking order theory, companies tend to prioritize to use internal rather than external funds of funds. This is because if the company uses external funding will increase the risks and obligations that must be paid by the company. Profitability negatively related to capital structure means higher corporate profits then the possibility of using the company's debt will be smaller. This means that the property and real estate company apply the pecking order theory.

Results of statistical regression to the variable firm size amounted to 0.001974 , statistical t-test results for the variable size of the company amounted to 0.7188 is greater than 0.05 means that the firm size is not significant positive effect on the capital structure. So that the second alternative hypothesis is rejected.

The firm size has a positive relation to capital structure. Companies that have large size will require more capital to meet the needs of companies (Riyantina \& Ardiansari, 2017). Companies that have large size will tend to use more debt. This is because large companies that have large funding requirements. According to Pujiharjanto et al. (2014), large-sized companies more diversified so that the likelihood of lower financial distress. Therefore, large companies tend to be easier to get funding from external parties. This is because large companies have a pretty good reputation in the eyes of society so that it will easily be trusted to obtain loans from lenders and investors debt.

Based on the pecking order theory, companies should be better prioritizing the use of funding coming from the company rather than from outside the company. Large companies will have greater sales levels so that the funds in the company will increase. Companies should use the funds to finance the company, so the company does not need to use debt for funding. However, research 
shows that a large company would be inclined to use debt for the company a great opportunity to be easier to obtain loans because they have greater access to capital markets, in addition to a large company is also able to reduce the transaction costs related to the issuance of long-term debt (Utomo, 2014). It can be concluded that the property and real estate company do not apply pecking order theory.

Firm size did not significantly effect on the company's capital structure this is because lenders and investors who will lend or invest in a company does not only consider the firm size but will also consider other factors such as the company's prospects, the nature of the company's current management and others (Wirawan et al., 2017). The result of this positive effect was not significant consistent with research conducted by (Yulianto et al., 2016; Sari \& Oetomo, 2016).

Results of statistical regression to the variable asset growth of 0.570675 , statistical results of the t-test for variable asset growth of 0.0000 less than 0.05 means that the asset growth has a significant positive effect on the capital structure. So the third alternative hypothesis is accepted. These results are consistent with research (Joni \& Lina, 2010).

Asset growth has a significant positive correlation to the capital structure. This means Companies that have high asset growth will tend to use more debt; this is because companies with a high growth rate of the capital need relatively large, so the company will rely on the use of external funds in the form of debt. According to Lin and Hung (2012), the company that wants great growth opportunities requires considerable funding for expansion cannot rely on internal funds are limited, so the company can borrow funds from external parties to fund the company's activities.

This is consistent with the pecking order theory; companies will prioritize the use of internal funds first, if not sufficient it will take the form of debt financing sources to issue shares. In companies that have high growth rates would have the full confidence of investors and creditors, these companies will be more likely to use external resources derived from debt as a source of funding, so that a higher proportion of debt than equity. This means that the property and real estate company apply the pecking order theory.

Results of statistical regression to the variable asset structure of 0.016675 , statistical results of the t-test for variable asset structure of 0.8536 is greater than 0.05 means that the asset structure is not significant positive effect on the capital structure. So the fourth alternative hypothesis is rejected. Companies that have a proportion of a larger asset structure will tend to have high levels of debt. Great asset structure which would allow companies to get loans because lenders feel more secure in lending to companies that have a large asset structure. The assets pledged as collateral, if someday in the future the company failed to meet its obligations then the presence of such assets may be used to meet their debt obligations.

Based on the pecking order theory, companies should be better prioritizing the use of funding coming from the company rather than from outside the company. When companies have a fixed proportion of larger assets, the valuation of its assets to more easily so that the problem of information asymmetry becomes lower. Thus, the company will reduce the use of debt while increasing the proportion of fixed assets. However, research shows that company with great asset structure will tend to use debt, this is because the greater the assets that can be pledged as security (collateral assets) by the company in obtaining a loan debt. If the structure of the assets of the company increased, the company would use a lot more debt. It can be concluded that the property and real estate company do not apply pecking order theory.

Assets structure did not significantly affect the company's capital structure due to property and real estate companies tend to have a lot of fixed assets such as land and buildings. However, the land and the building were relatively difficult to be converted into cash which will be used by the company to pay off its obligations if the company has trouble funding. Thus, the assurance of fixed assets does not have a high economic value for creditors. The result of this positive effect was not significant consistent with research conducted by (Sari \& Haryanto, 2013; Noor et al., 2015). Results of statistical regression to the variable liquidity of -0.028489 , statistical results of the t-test for liquidity of 0.0042 less than 0.05 means that the liquidity has a significant negative effect on the capital structure. So the fifth hypothesis is accepted. These results are consistent with research (Hamidah, 2016).

Liquidity is negatively related significantly to the capital structure, means that companies that have high levels of liquidity may reduce the use of debt in the composition of company financing, this is because companies with high liquidity have internal funds in a large company, so the company would prefer to use internal funds to meet the financing needs of companies rather than using external funds in the form of debt. 
Based on the pecking order theory, the company will give priority to the use of internal funds to the funding needs of companies rather than using external funds. Due to the use of external funds will increase the obligations of the company which will be paid companies. Liquidity is negatively related to capital structure means that the higher level of liquidity of the company then the possibility of using the company's debt will be smaller. This means that the property and real estate company apply the pecking order theory.

\section{CONCLUSION AND RECOMMENDATION}

Profitability and liquidity have a significant negative effect on capital structure. Asset growth has a significant positive effect on capital structure. While the firm size and asset structure had no significant positive effect on the capital structure. For further research, the results of this study can be used as a reference for conducting research on capital structure policy. In addition, further research is expected to add a proxy of the variable that affects the company's capital structure.

For the company, management is expected to make the capital structure the company can pay attention to the variables that significantly affect the capital structure as variable profitability, asset growth and liquidity as a consideration in order to determine the optimal capital structure the company so as to minimize the capital costs incurred by the company.

For investors before committing capital investment to the property and real estate company should take into account the variables that affect the company's capital structure and shows a significant result is a profitability, asset growth and liquidity.

\section{REFERENCES}

Brigham, E. F., \& Houston, J. F. (2006). Dasar-Dasar Manajemen Keuangan (Edisi 10). Jakarta: Salemba Empat.

Brigham, E. F., \& Houston, J. F . (2014). Dasar-Dasar Manajemen Keuangan (Edisi 11 B). Jakarta: Salemba Empat.

Brigham, E. F., \& Weston, J. F. (2005). Dasar-Dasar Manajemen Keuangan (Edisi 9). Jakarta: Erlangga.

Hadianto, B. (2008). Pengaruh Struktur Aktiva, Ukuran Perusahaan dan Profitabilitas terhadap Struktur Modal Emiten Sektor Telekomunikasi Periode 2000-2006: Sebuah Pengujian Hipotesis Pecking Order. Jurnal Manajemen, 7(2), 14-29.

Hamidah. (2016). Analysis of Factors Affecting the Capital Structure and Profitability in Indonesian's Manufacturing Company Year 2009-
2013. Jurnal Keuangan dan Perbankan, 20(2), 157-165.

Hartoyo, A. K. W., Khafid, M., \& Agustina, L. (2014). Faktor-Faktor yang Mempengaruhi Struktur Modal Perusahaan Tekstil dan Garmen di BEI. Accounting Analysis Journal, 3(2), 247-254.

Haruman, T. (2008). Pengaruh Struktur Kepemilikan terhadap Keputusan Pendanaan (Perspektif Agency Theory). Survey pada Perusahaan Manufaktur di PT. Bursa Efek Indonesia. $\mathrm{Na}$ tional Conference on Management Research.

Haryanto, S. (2014). Identifikasi Ekspektasi Investor melalui Kebijakan Struktur Modal, Profitabilitas, Ukuran Perusahaan dan GCPI. Jurnal Dinamika Manajemen, 5(2), 183-199.

Hendratmoko, S. L., \& Laily, N. (2017). Pengaruh Ukuran Perusahaan, Profitabilitas dan Pertumbuhan Aset terhadap Struktur Modal. Jurnal Ilmu dan Riset Akuntansi, 6(8), 1-15.

Indrajaya, G., Herlina, \& Setiadi, R. (2011). Pengaruh Struktur Aktiva, Ukuran Perusahaan, Tingkat Pertumbuhan, Profitabilitas dan Risiko Bisnis terhadap Struktur Modal: Studi Empiris pada Perusahaan Sektor Pertambangan yang Listing di Bursa Efek Indonesia Periode 2004-2007. Jurnal Ilmiah Akuntansi, 6(2), 1-23.

Indriani, A., \& Widyarti, E. T. (2013). Penentu-Penentu Struktur Modal Perusahaan yang Sahamnya Masuk Jakarta Islamic Index. Jurnal Dinamika Manajemen, 4(1), 59-68.

Joni, \& Lina. (2010). Faktor-Faktor yang Mempengaruhi Struktur Modal. Jurnal Bisnis dan Akuntansi, 12(2), 81-96.

Kartika, A. (2009). Faktor-Faktor yang Mempengaruhi Struktur Modal pada Perusahaan Manufaktur yang Go Publik di BEI. Dinamika Akuntansi Keuangan dan Perbankan, 1(2), 105-122.

Liang, L., Li, L. F., \& Song, H.-S. (2014). An Explanation of Capital Structure of China's Listed Property Firms. Property Management, 32(1), 4-15.

Lin, F. L., \& Hung, J. Y. (2012). Internationalization and Capital Structure of Taiwan Electronic Corporations. International Business Research, 5(1), 164-171.

Maftukhah, I. (2013). Kepemilikan Manajerial, Kepemilikan Institusional dan Kinerja Keuangan sebagai Struktur Modal Perusahaan. Jurnal Dinamika Manajemen, 4(1), 69-81.

Nirmala, A., Moeljadi, \& Andarwati, A. (2016). Pengaruh Ukuran Perusahaan, Profitabilitas, Pertumbuhan Penjualan dan Kepemilikan Manajerial terhadap Struktur Modal dan Nilai Perusahaan Manufaktur di Indonesia (Perspektif Pecking Order Theory). Jurnal Aplikasi Manajemen, 14(3), 557-566.

Nisak, N. K., \& Ardiansari, A. (2016). Analisis FaktorFaktor yang Mempengaruhi Struktur Modal serta Pengaruhnya terhadap Harga Saham pada Perusahaan-Perusahaan yang Tergabung. Management Analysis Journal, 5(2), 88-95.

Noor, T., Sinaga, B., \& Maulana, T. N. A. (2015). Test- 
ing on Pecking Order Theory and Analysis of Company's Characteristic Effects on Emitten's Capital Structure. Indonesian Journal of Business and Entrepreneurship, 1(2), 81-89.

Nugraha, A. A. (2013). Analisis Pengaruh Struktur Modal terhadap Kinerja Perusahaan yang Tergabung dalam Indeks Kompoas 100. Management Analysis Journal, 2(1), 1-7.

Nugroho, N. C. (2014). Analisis Pengaruh Profitabilitas, Pertumbuhan Penjualan, Ukuran Perusahaan dan Umur Perusahaan terhadap Struktur Modal Usaha Mikro Kecil dan Menengah Kerajinan Kuningan di Kabupaten Pati. Management Analysis Journal, 3(2), 6-10.

Nuswandari, C. (2013). Determinan Struktur Modal dalam Perpekstif Pecking Order Theory dan Agency Theory. Dinamika Akuntansi Keuangan dan Perbankan, 2(1), 92-102.

Oktavilia, S., Fafurida, \& Khoiruddin, M. (2017). Mappings Industry as the Strategy for Enhancing Competitiveness of Industry in Semarang Regency. American Scientific Publishers, 23(8), 7131-7134.

Pujiharjanto, C. A., Nilmawati, \& Gusaptono, R. H. (2014). Identifikasi Variabel Penentu Struktur Modal dan Adjusment to Target Capital Structure: Trade off Theory. Jurnal Keuangan dan Perbankan, 18(3), 358-369.

Ridloah, S. (2010). Faktor Penentu Struktur Modal: Studi Empirik pada Perusahaan Multifinansial. Jurnal Dinamika Manajemen, 1(2), 144-153.

Riyantina, R., \& Ardiansari, A. (2017). The Determinants of Capital Structure on Consumer Goods Company Period 2011-2014. Management Analysis Journal, 6(1), 23-35.

Riyanto, B. (1995). Dasar-Dasar Pembelanjaan Perusahaan. Edisi Keempat. BPFE. Yogyakarta.

Bambang, R. (2001). Dasar-Dasar Pembelanjaan Perusahaan. Edisi Keempat, Cetakan Ketujuh, BPFE Yogyakarta, Yogyakarta.

Sansoethan, D. K., \& Suryono, B. (2016). Faktor-Faktor yang Mempengaruhi Struktur Modal pada Perusahaan Makanan dan Minuman. Jurnal Ilmu dan Riset Akuntansi, 5(1), 1-20.

Insiroh, L. (2014). Pengaruh Profitabilitas, Ukuran Perusahaan, Pertumbuhan Aset dan Struktur Aset terhadap Struktur Modal. Jurnal Ilmu Manajemen (JIM), 2(3), 979-990.

Sari, V. D., \& Haryanto, A. M. 2013. Pengaruh Profitabilitas, Pertumbuhan Aset, Ukuran Perusahaan, Struktur Aktiva dan Likuiditas terhadap Struktur Modal pada Perusahaan Manufaktur di Bursa Efek Indonesia Tahun 2008-2010. (Doctoral dissertation, Fakultas Ekonomika dan Bisnis). Diponegoro Journal of Management, 2(3), 1-11.

Seftianne, \& Handayani, R. (2011). Faktor-Faktor yang Mempengaruhi Struktur Modal pada Perusahaan Publik Sektor Manufaktur. Jurnal Bisnis dan Akuntansi, 13(1), 39-56.
Sudana, I. M. (2015). Teori dan Praktek Manajemen Keuanagnan Perusahaan (Edisi Kedua). Jakarta: Erlangga.

Sutrisno, S. (2016). Struktur Modal: Faktor Penentu dan Pengaruhnya pada Nilai Perusahaan. Jurnal Siasat Bisnis, 20(1), 79-89.

Thesarani, N. J. (2016). Pengaruh Ukuran Dewan Komisaris, Kepemilikan Manajerial, Kepemilikan Institusional dan Komite Audit terhadap Struktur Modal. Nominal, Barometer Riset Akuntansi dan Manajemen, 6(2), 1-13.

Utomo, P. (2014). Pengaruh Variabel Fundamental terhadap Struktur Modal dan Dampaknya terhadap Nilai Perusahaan. Jurnal Aplikasi Manajemen, 11(3), 374-383.

Wachowicz Jr, J. M., \& Van Horne, J. C. (2005). Prinsip-Prinsip Manajemen Keuangan. Jakarta, Salemba Empat.

Wahyuni, S. (2012). Efek Struktur Modal terhadap Profitabilitas pada Perusahaan Manufaktur yang Terdaftar di Bursa Efek Indonesia. Mangement Analysis Journal, 1(2), 1-5.

Weston, F. J., \& Copeland, T. E. (1996). Manajemen Keuangan Buku 2 Terjemahan Yohannes Lamarto. Jakarta: Erlangga.

Wibowo, A., \& Wartini, S. (2012). Efisiensi Modal Kerja, Likuiditas dan Leverage terhadap Profitabilitas pada Perusahaan Manufaktur di BEI. Jurnal Dinamika Manajemen, 3(1), 49-58.

Widodo, M. W., \& Djawahir, A. H. (2014). Pengaruh Tangibility, Profitabilitas, Pertumbuhan Perusahaan, Non Debt Tax Shields, Cash Holding dan Ukuran Perusahaan terhadap Struktur Modal Perusahaan (Studi pada Perusahaan Manufaktur yang Listing di BEI Tahun 20102012). Jurnal Aplikasi Manajemen, 12(1), 143150.

Wikartika, I., \& Fitriyah, Z. (2017). Testing Pecking Order Theory in Jakarta Islamic Index. Manajemen Bisnis-MEBIS, 1(2), 11-22.

Wimelda, L., \& Marlinah, A. (2013). Variabel-Variabel yang Mempengaruhi Struktur Modal pada Perusahaan Publik Sektor Non Keuangan. Media Bisnis, 5(3), 200-213.

Wirawan, P. A., Tripalupi, L. E., \& Zukhri, A. (2017). Pengaruh Struktur Aktiva, Profitabilitas, Ukuran Perusahaan dan Likuiditas terhadap Struktur Modal pada Perusahaan Sektor Barang Konsumsi yang Terdaftar di Bursa Efek Indonesia Periode Tahun 2014-2015. Jurnal Pendidikan Ekonomi Undiksha, 9(1).

Firnanti, F. (2011). Faktor-Faktor yang Mempengaruhi Struktur Modal Perusahaan Manufaktur di Bursa Efek Indonesia. Jurnal Bisnis dan Akuntansi, 13(2), 119-128.

Yulianto, A., Suseno, D. A., \& Widiyanto, W. (2016). Testing Pecking Order Theory and Trade Off Theory Models in Public Companies in Indonesia. International Journal of Economic Perspectives, 10(4), 21-28. 